$\square$ 증 례

$$
\text { 폐내엽형 폐격리증 1예 }
$$

국립의료원 내과

장 대 환

국군수도병원 내과

이 현 제·한 상 호-박 용 준

방 사 선 과

양

승

오

병 리 과

박 용 구

연세대학교 의 과대학 내과학교실

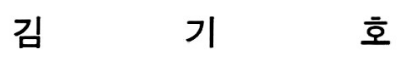

$=$ Abstract $=$

\title{
Pulmonary Sequestration
}

-Report of 1 Case-

Dae Hwan Jang, M.D.

Department of Internal Medicine, National Medical Center, Seoul, Korea

Hyun Je Lee, M.D., Sang Ho Han, M.D. and Young Jun Park, M.D.

Department of Internal Medicine, Captial Armed Forces General Hospital

Seoung Oh Yang, M.D.

Department of Radiology, Capital Armed Forces General Hospital, Seoul, Korea

Yong Koo Park, M.D.

Department of Pathology

Ki Ho Kim, M.D.

Department of Internal Medicine, College of Medicine, Yonsei University, Seoul, Korea

Pulmonary sequestration is a congenital lesion in which a system artery supplies a cystic portion of the lung in which its bronchus usually does not communicate with the remainder of the bronchial 
tree. There are two types of sequestration recognized. Intralobar pulmonary sequestration recog. nized. Intralobar pulmonary sequestration is usually contained within the visceral pleura of the pulmonary venous system. Extralobar pulmonary sequestration is usually within a pleural sheath of its own and the venous drainage is to the azygos hemiazygos system. We experienced a case of pulmonary sequestration preoperatively confirm chest film showed a large mass lesion at the left lower posterior basal lung field. Aortagram confirmed an aberrant artery originated from thoracic aorta just above the diaphragm and drained via pulmonary vein into the left atrium.

At time of operation, a large abscess cavity measuring $12 \times 8 \times 7 \mathrm{~cm}$ in dimension at the left lower lobe was noted. Aberrant artery, measuring $0.5 \mathrm{~cm}$ in diameter and $2 \mathrm{~cm}$ in length, arising from thoracic aorta just above the diaphragm was noted.

A case of pulmonary sequestration was reported with the review of the literature.

\section{서 론}

폐 격리증은 비교적 드문 선천성 폐질환으로서 폐엽 일 부가 낭포성 병변을 나타내며 대동맥으로부터 직접 분지 되는 비교적 큰 동맥을 통해서 혈액 공급을 받는 질환이 다 ${ }^{1,2)}$.

Huber는 폐로 가는 비정상적인 체동맥을 최초로 보고 하였고, $\mathrm{McCotter}^{3}$ 가 임상적으로 자세히 기술하였으며 Harris와 Lewis')는 폐절제를 한 후 비정상적인 체동맥 으로부터 출혈로 인하여 사망한 예는 보고하였다.

본 국군수도병원 내과에서는 폐내엽형 폐격리증 1 예를 선택적 대동맥조영술로 확진하여 본원 훙부외과에서 수 술하여 호전된 1예를 경험하여 문헌고찰과 함께 보고하 는 바이다.

증 례

환 자 : 조석, 21 세, 남자.

주 소:좌흉통 및 호흡곤란.

현병력 : 입원 3 일전부터 좌흥통, 발열, 전신피로감 및 호흡곤란이 있었으며 각혈이나 화농성객담은 없었다.

과거력 : 국민학교때 폐렴을 않은 적이 있었으며 그 이 후 반복되는 상기도감염이 있었으며 그때마다 기침 오한 발열 등의 증상이 심했다.

가족력 : 특이사항 없음

이학적 소견 : 입원 당시 환자의 체온은 $39.4^{\circ} \mathrm{C}$, 혈압 은 $100 / 60 \mathrm{mmHg}$, 맥박은 95 회/분, 호흡수는 30 회/분 이었다. 좌측하엽부분의 호흡음은 감소되었고, 좌홍부에 압통이 있었으며 타진상 탁음을 수반하였고, 심음은 정 상이었다.
검사 소견 : 내원당시 혈액검사상은 혈 색소는 $11.7 \mathrm{gm}$ $\%$, 백혈구는 $13,100 / \mathrm{mm}^{4}$, 적혈구 침강속도는 $55 \mathrm{~mm} /$ $\mathrm{hr}$ 로 증가되어 있으며, 일반뇨검사상은 정상범위이었으 며 결핵도말검사 및 세균학적 배양검사는 음성이었다. 단 순흉부 X-선 검사는 좌하엽에 심음영과 중첩되어 균일 한 음영을 나타내는 종괴가 있었다(Fig. 1).

치료 및 경과 : 매일 crystal penicillin 2000만 $\overline{\mathrm{u}}$ 와 Gentamycin $160 \mathrm{mg}$ 을 투여하여 4주간 치료하였으며 내 과적 치료를 시행함에 따라 단순 훙부 X-선상 좌하엽의 종괴음영 크기가 감소되어 갔다(Fig. 2). 기관지조영술 에서는 기관지에는 이상이 없었으며 촤하엽부위에 종괴 로 인해서 기관지가 밀려 있었으며 종괴부위로 조영제의 병변내 유입은 보이지 않았다(Fig. 3). 초음파검사상 홍

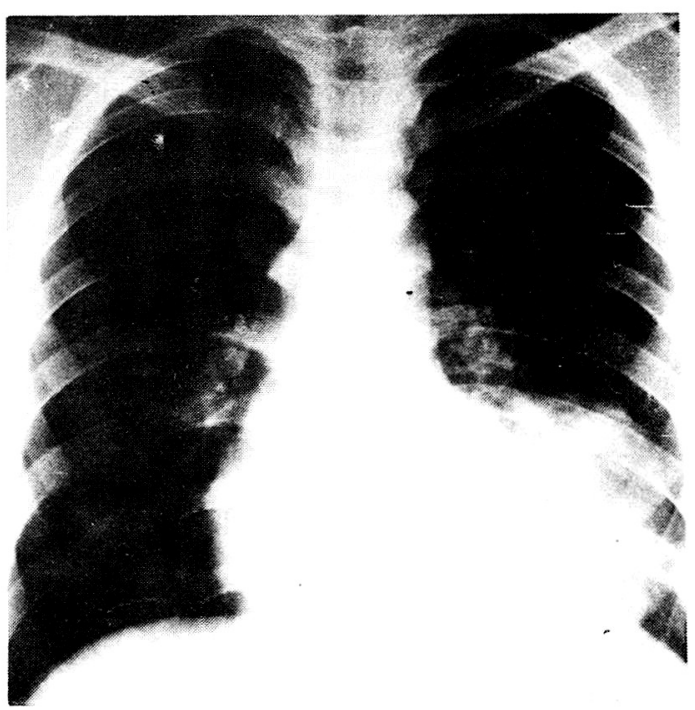

Fig. 1. Relatively well demarcated round soft tissue mass density at left lower lobe is shown which minimcs mass lesion. 
부대동맥에서 기시하여 좌하엽으로 유입되는 혈관분지를 볼 수 있었으며 (Fig. 4), 전산화 훙부단층촬영상에 좌측 폐하엽에 농양을 의심케 하는 종괴가 나타났으며 (Fig. $5)$, 내과적 치료후 다시 찍은 사진에서 폐종괴의 음영은 소실되었으나, Enbanced되는 삼각형의 잔재음영이 남 아 있었다(Fig. 6). 대동맥조영술과 선택적 혈관조영술
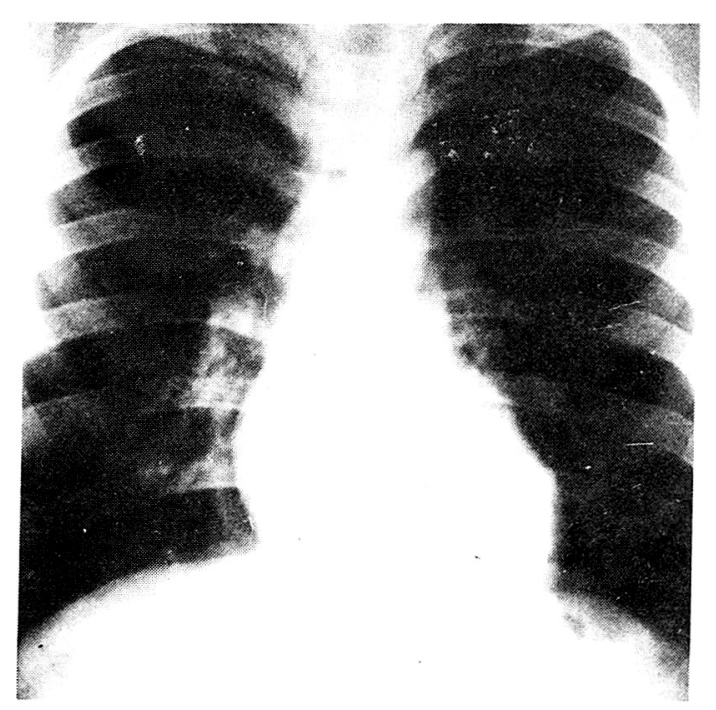

Fig. 2. Follow up 4 week. The lesion is decreased in size and isn't across the left cardiac border on the PA view.

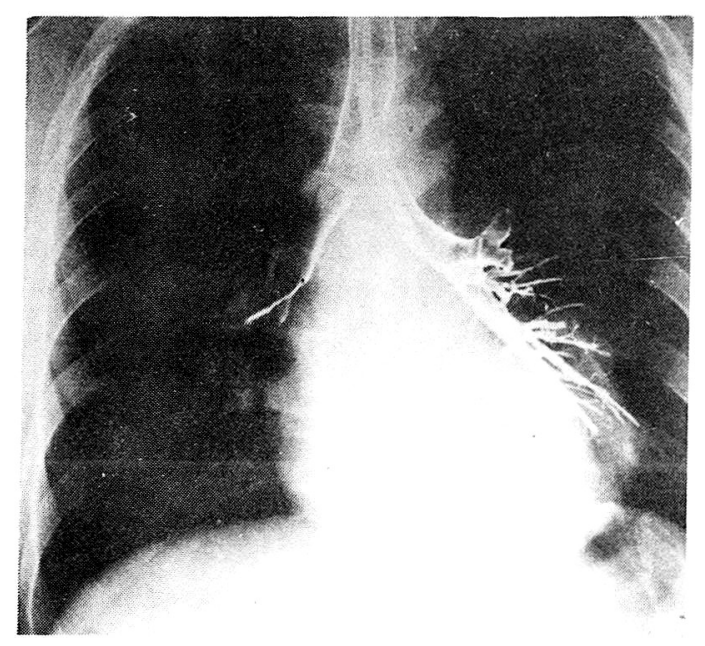

Fig. 3. Left lower lobe mass lesion is not communicated with bronchus and makes regional bronchial trees ciisplaced laterally.
상 직경 $5 \mathrm{~mm}$ 정도의 이상동맥이 향부동맥에서 기시되 어 병변부위에 분포하는 것을 보여 주었다(Fig. 7). 폐 격리증이란 진단하에서 훙부외 과에 전 과하여 이상동맥분 단결찰 및 좌하엽절제술을 시행하였다.

병리학적 소견 : 절제된 좌폐하엽은 크기가 $12 \times 8 \times 7$ $\mathrm{cm}$ 이었다. 이상동맥을 관통하여 절제된 활면상에서 병 소의 크기는 $4 \times 5 \mathrm{~cm}$ 이었다. 비쿄적 남아 있는 폐실질 과 구분이 잘되었다. 이상동맥을 중심으로 흰색의 섬유 화된 양상을 보이며 크고 작은 낭상변화를 보이고 있었

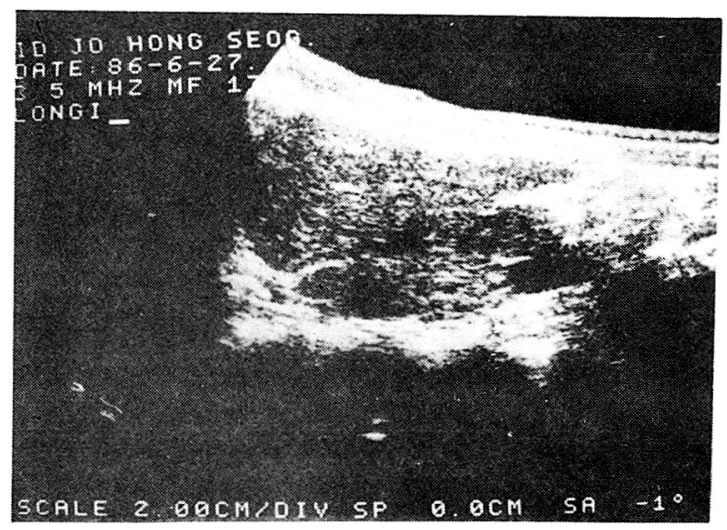

Fig. 4. Ultrasonography for the detection of abnormal artery supplying the lesion-about $5 \mathrm{~mm}$ width tubular vascular structure is identified at diaphragmatic level of the abdominal aorta.

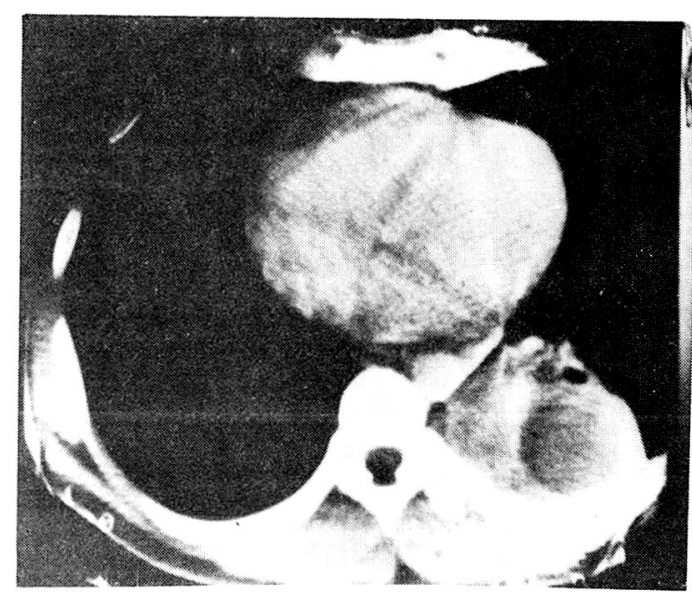

Fig. 5. Initial C-T section shows thick-walled low density lesion and triangular high density lesion intermingled with left lower lobe along the aorta. 
다. 이상동맥의 직경은 $0.5 \mathrm{~cm}$ 이었다. 현미경적 소견상 병소는 기관지와 구분되어 있으며 부위에 따라 낭상구조 를 하고 있었다.

이 낭상구조는 주로 호흡상피들로 덮여 있으며 기관지 의 모양을 하고 있고 주위를 섬유근육성 조직 또는 섬유 성교질 조직이 구획을 나누고 있었다. 많은 부위에서는 호흡상피들은 탈락되어 있기도 하였다. 그 밑에는 만성 염증세포들의 침윤을 관찰할 수 있었다. 연골구조도 관 찰되며, 주위의 폐포조직은 폐렴의 소견을 보이며 동시 에 섬유근육성과 과형성을 보였고, 급성삼출성 기관지 염, 폐렴, 콜레스테롤 육아종도 관찰이 되었다. 비교적

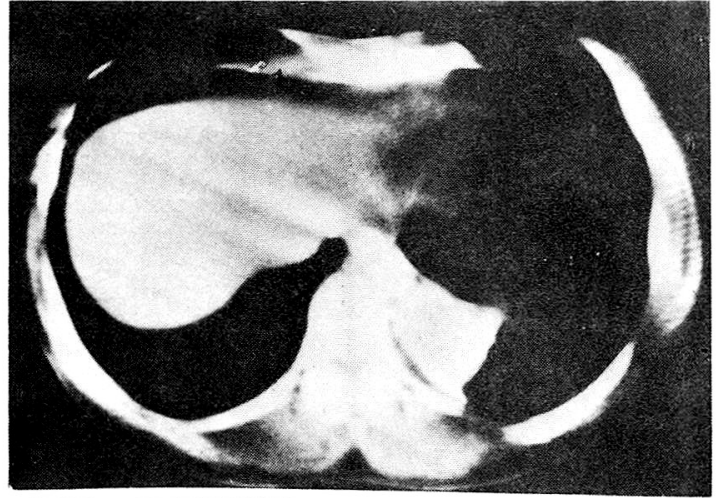

Fig. 6. Follow up CT after 2 week from Fig. 5. Shows total resolution of the lung abscess area and residual highly enhanced triangular area.

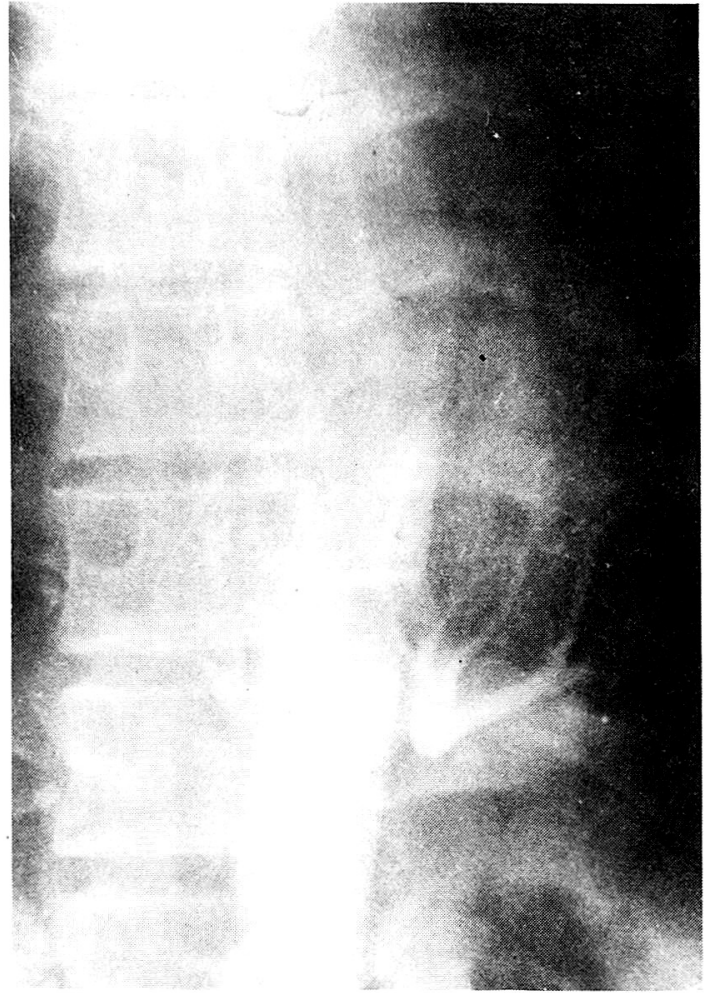

Fig. 7. Selective arteriography confirm the diagnosis of the pulmonary sequestration of the left lower lobe which supplied from abnormal artery from descending aorta and drained into left lower pulmonary vein.

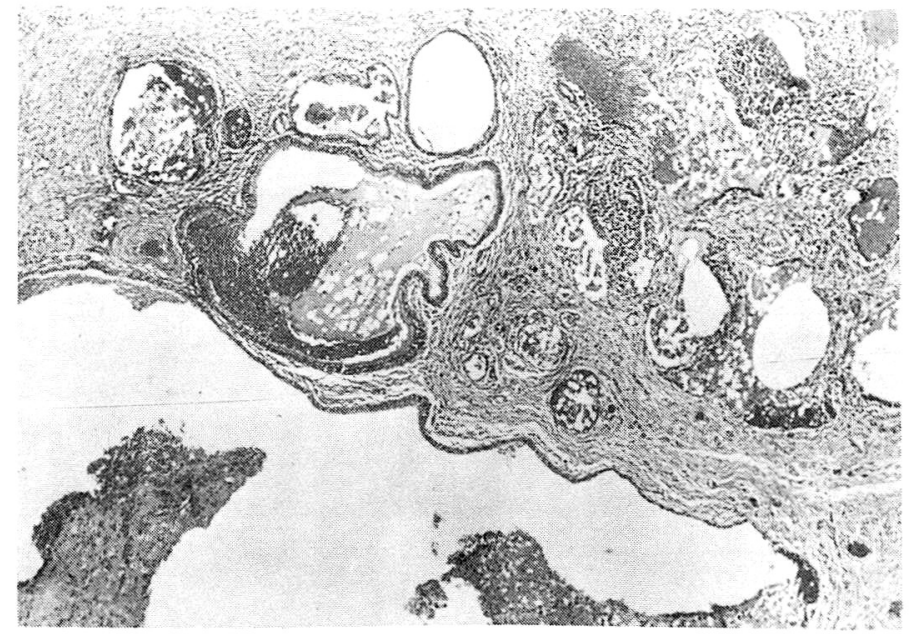

Fig. 8. Microscopic picture of the sequestered portion showing varying sized dilated bronchiolar structures among fibrous background. (H\&E, x100). 


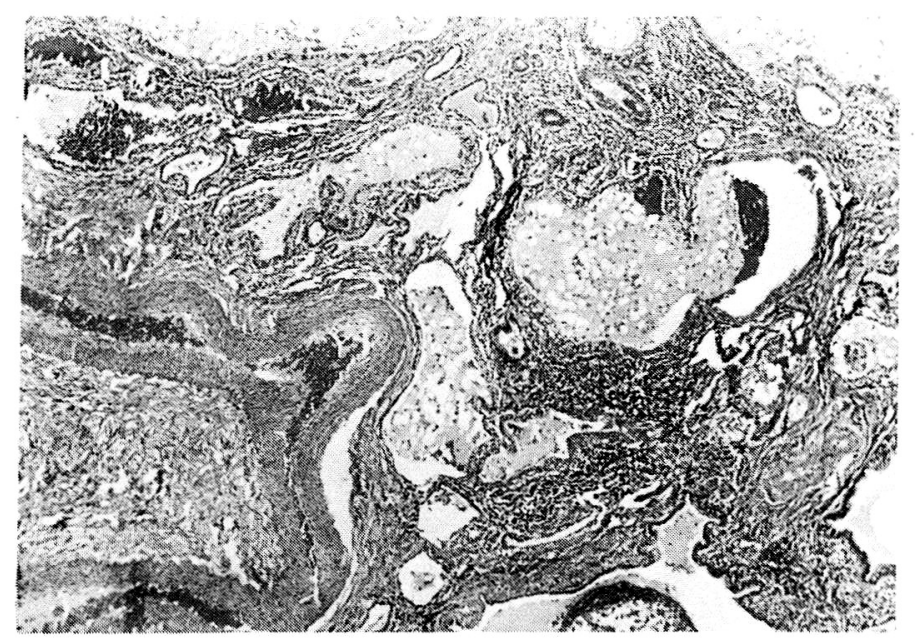

Fig. 9. Elastic type of feeding arteriole is present with infiltration of chronic inflammatory cell in the interstitium (H\&E, $\times 100)$.

큰 탄성형 동맥이 관찰되었다(Fig. 8,9).

\section{고 찰}

폐 격리증은 드문 선천성 질환으로서 1946년 $\mathrm{Pryce}^{5)}$ 가 Seguestration란 말을 사용한 후 많은 발표가 있었 는데, 발생기전은 1902년에 Eppinger와 Schauenstein ${ }^{6)}$ 은 정상적인 폐아체의 후측으로 태아의 전정 (foregut)에 서 부가적인 기관지아체가 발생한다고 하였으며, 이 다 잠성조직 (pleuripotential tissue)에 자체의 혈관과 함께 정상적으로 발달하여 미측으로 이동하여 폐격리증을 만 드는 선천성 기형이라고 주장하였다. Gebeue Mason ${ }^{7)}$ 은 폐의 일부분이 염증성변화에 이차적으로 나타난 기관 지 혹은 종격동혈관의 비대로 인하여 후천적으로 생긴다 는 설을 주장했으나, 일반적으로 선천성 이상으로 받아 들여지고 있다. Pryce5)은 견인설 (traction theory) 을 제 안하여 폐를 공급하는 대동맥의 이상분지가 태생기에 폐 의 일부구역을 끌어 당김으로써 정상적인 조직에서 분리 되고 장애를 받아 발생한다고 하였다. Smith ${ }^{8)}$ 는 폐격리 증이 초기의 폐동맥의 주분지가 폐분절에 도달하는 것에 실패해서 생기는 것으로 설명하였다.

남녀의 비는 남자가 많으며 Bruwer등은 2: 1, Allen 은 $3: 2$ 로 보고하였다. 호발 부위는 좌측이 우측보다 많 고 하엽 특히 후기저부에 호발한다 ${ }^{13,14)}$.

폐격리증의 분류는 폐엽내형 (Intralobar type)와 폐엽
외형 (Extralobar type)으로 나누어지며 폐엽내형은 정 상폐와 공동늑막을 가지고 있으며 폐엽외형은 그 고유늑 막으로 싸여 있다.

Wall과 Lucido9)에 의하면 100예의 비정상적 체동맥 중 향부대동맥에서 기시한 것이 $13 \%$ 이라 하였다. $\mathrm{McCotter}^{3)}$ 은 9예의 비정 상적인 체동맥중 7예가 홍부 대 동맥에서, 1 예가 복부대동맥에서 그리고 1 예는 늑간동맥 에서 기시하였다고 보고하였으며, Carter ${ }^{10)}$ 는 10 15\% 에서 횡경막하 복부대동맥 또는 복강동맥계(Celiac artery systam)에서 기시한다고 보고하였다.

이상동맥은 대개 단독으로 있으며 직경이 5 20 mm 에 해당하고, $3 \mathrm{~mm}$ 이하인 경우에는 다발성으로 나오는 경우가 많다. 간혹 다발성인 경우에는 횡경막의 상부와 하부에서 이상동맥이 따로 나올 수 있으며 내엽성의 15 $\%$, 외엽성의 $20 \%$ 에서 나타날 수 있다 ${ }^{10)}$. 정맥환류는 페 엽내형인 경우 대개 하부폐정맥을 통하여 환류되고 간혹 기정맥이나 반기정맥, 늑간정맥, 혹은 무명정맥을 통하 는 경우가 있다. 그 외에 전신정맥과 폐정맥 양쪽으로 환 류되는 경우도 있다. 외엽성형에서는 폐정맥으로 환류되 는 경우는 드물고, 주로 기정맥 혹은 반기정맥계통, 그 리고 드물게 간문맥, 늑간정맥, 식도정맥, 쇄골하정맥을 통해서 환류된다 ${ }^{11,121}$. $\mathrm{Pryce}^{5)}$ 는 이상동맥의 분포에 따 라 4 Type으로 분류하였는데 그에 따르면 폐격리증이 없 이 이상동맥만 분포하는 것을 Type 1 , 폐격리증 부위와 주위의 정 상조직에까지 이상동맥이 분포한 것은 Type 2 , 
폐격리증의 부위에만 이상동맥이 분포한 것을 Type 3, 폐격리증 부위에 이상동맥이 없고 단지 폐동맥이 분포하 고 있는 것을 Type 4라 하였다.

Iwail등 ${ }^{18)}$ 은 병소의 육안적 및 현미경적 소견을 종합 하여 13예를 $4 \mathrm{Grade}$ 로 분류하였다. 그들에 따르면 폐 격리증이 큰 기관지벽으로만 구성되는 것을 Grade 1 (1 예), 다수의 낭상변화를 보이는 것은 Grade 2(3예), 낭 상구조와 폐포구조로 구성된 것을 Grade 3(6예), 폐포 구조로만 구성된 것을 Grade 4(1예)라 하였다. 본예는 Pryce 분류에 따르면 Type 3, Iwaii등의 Grade 3에 해 당한다 하겠다.

감별진단을 요하는 질환군은 낭상기관지 확장증, 폐의 선천성 선종양 기형을 포함한 선천성 낭상질환들을 들 수 있다. 폐격리증은 특이하게 폐좌하엽 후기저부에 호발하 고 주기관지와 연결이 없으며, 탄분침착이 없는 점등이 비교적 다른 질환들과의 감별을 용이하게 해준다.

내엽성형에서 다른 선천성기형을 동반하는 경우가 드 물지만 외엽성형에서는 반정도에서 다른 기형을 동반하 며, 선천성 횡격막 탈장에 제일 많이 나타난다 ${ }^{15)}$. 임상 소견으로 내엽성형에서 증상이 없이 단지 흥강내 종양으 로 나타날 수도 있으나, 대개는 증상을 동반하며 주로 반 복되는 폐의 감염으로 고열, 오한, 흥통, 기침, 객담 등 이 있을 수 있어 폐렴이나 기관지확장증, 폐농양, 농훙, 혹은 악성종양과 감별을 요하게 된다 ${ }^{16)}$. 식도나 위로 연 결이 있는 폐격리증에서는 연하곤란, 오심, 구토, 토혈 이 나타날 수 있는 데 식도나 위가 국한성 압박을 받거 나 혈액이나 염증성 물질이 위나 식도로 들어가서 나타 난다 ${ }^{12)}$. 또한 드물게 심맥관증상을 일으킬 수 있는 데 ${ }^{12,17)}$, 이는 폐정맥으로 환류되면서 Left to Left shunt 을 일으켜 심박출량의 증가로 울혈성 심부전 증상을 일 으킬 수 있다 ${ }^{12,18)}$.

폐격리증에서 단순흥부 X-선상은 고형의 또는 액체가 차 있는 낭포를 나타내며 다발성낭포를 형성하기도 하나 보통은 한개의 커다란 낭포로 좌폐후기저부에 위치한 다 ${ }^{12,14)}$. 기관지조영상 대부분 기관지와 연결이 없으며 주 위 기관지의 변위를 보여 주며미 조영제가 격리된 조직 으로 들어가는 경우는 대단히 드물다. 그리고 술전 역행 성 혈관조영술은 1959 년 Simopoulos ${ }^{14}$ 가 처음 기술하 였으며 Lindstog ${ }^{19)}$ 은 기형동맥의 정 확한 위치를 알아 수 술에 안전을 기할 수 있다고 기술하였다. Kawakami 등 ${ }^{20)}$ 은 동위원소를 이용하여 폐격리증을 진단하였는데 lung perfusion scan에 의하여 나오는 perfusion defect 는 폐격리증의 특이한 소견은 아니나 훙부 X-선상에서 낭종구조를 보이는 소견이 후기저부에 나티 구면 폐격리 증으로 의심할 수 있다.

치료는 대개 페엽외형은 고유늑막에 싸여 있어서 격리 부만 절제할 수 있으나 폐엽내형은 염증성 변화로 정상 폐와 붙어 있어 대개 폐엽절제술이 필요하다 ${ }^{12}$.

\section{결 론}

본 국군수도병원내과에서 술전에 확진한 폐격리증 1 예 를 경험하여 문헌고찰과 함께 보고하는 바이다.

\section{REFERENCES}

1) Culiner MM, Wall CA: Collateral ventilation intralobar pulmonary sequestration. Dis Chest 47: 118, 1965

2) Cooley JC: Introlobar Bronchopulmonary sequestration. Dis Chest 42:95, 1962

3) McCotter RE: On the occurence of pulmonary arteries arising from the thoracic aorta. Anat Rec 4: 219, 1910

4) Harris HA, Lewis I: Anomalies of the lungs with special reference to the danger of abnormal vessles in lobectomy. J Thoracic Surg 9:666, 1940

5) Pryce DM, Sellors TH, Blair LG: Intralobar sequestration of lung associated with an abnormal pulmonary artery. Brit J Surg 35:18, 1947

6) Eppinger H, Schauenstein W: Krankheiten der Lungen . A. Angeborene krankheiten. Ergebn Allg Path Anat 8:267, 1902

7) Gebauer PW, Mason CB: Pulmonary sequestration associated with anomalous pulmonary vessels. Non entity, Dis Chest 35:282, 1959

8) Smith GA: Sone controversial aspects of introlobar sequestration of lung. Surg Gynec Obst 94:57, 1962

9) Wall CA, Lucido JL: Introlbar bronchopulmonary sequestration. Surg Gynec Obst 103:701, 1956

10) Carter R: Pulmonary sequestration collective review Ann Thorac Surg 7:68, 1969

11) Savic B, Birtel FJ, Fholen W, Funke HD, Knabe R: Lung sequestration Report of seven cases and review of 540 published cases. Thorax 34:96, 1979

12) Charles S, O'Mara R, Jeyasinghank: Pulmonary 
sequestration. Surg Gynec Obst 147:609, 1978

13) Kilman JW, Tsybi H, Vellio F, Batersby JS: Pulmonary sequestration Arch Surg 90:648, 1965

14) Simopoulos AP, Rosemblum DJ, Mozumdas H, Kiely B: Intralobar bronchopulmonary sequestration in children. Am J Dis Child 97:796, 1959

15) DePareds CG, Pierce WS, Johnson DG, Waldhausen JA: Pulmonary sequestration in infants and chil. dren. J Ped Surg 5:136, 1970

16) Domby WR, Clement P, FitzGerald MX, Gaensler EA: Giant intralobar sequestration. Respiration 35: 224, 1978
17) Flye MW, Conley M, Silver D: Spectrum of pulmonary sequestration. Ann Thoracic Surg 22:478, 1976

18) Iwaii $K$, Shindo G, Hajikono H: Intralobar pulmonary sequestration with special reference to developmental pathology. Am Rev Resp Dis 107:911, 1973

19) Turk LN III, Lindskog GE: Importance of angiography diagnosis in intralobar pulmonary sequestration. J Thoracic cardiovascular Surg 41:299, 1961

20) Kawakami K, Tada S, Katsuyama N, Mochizuki S: Radionuclide study in pulmonary sequestration. J Nucl Med 19:289, 1978 